\title{
IDENTIFIKASI Aspergillus sp PADA ROTI MANTAO YANG DI PERJUALBELIKAN DI KOTA MAKASSAR
}

\author{
Isna Rahmasari Burhanuddin ${ }^{1)}$, Dewi Arisanti ${ }^{1)}$, Mujahidah Basarang ${ }^{1)}$ \\ 1) Prodi D3 Teknologi Laboratorium Medis Politeknik Kesehatan Muhammadiyah Makassar \\ Email: dewiharimuswarah@gmail.com
}

\begin{abstract}
Abstrak
Roti mantao merupakan salah satu pangan semi basah yang biasa dikonsumsi oleh masyarakat. Roti mantao berwarna putih dan bertekstur empuk yang dapat disajikan dengan cara dikukus, dibakar, ataupun digoreng. Bahan utama untuk membuat roti mantao yaitu tepung terigu, gula, susu dan ragi. Pertumbuhan jamur yang sangat cepat pada roti mantao dikarenakan komposisi dari bahan dasar dari pembuatan roti mantao yang merupakan sumber nutrisi utama bagi mikroorganisme seperti Aspergillus sp. Jenis jamur ini juga merupakan kontaminan umum pada berbagai pangan, yang menyebabkan kerusakan pangan. Jamur terdapat pada bahan makanan, dan tumbuh dengan sangat cepat dengan koloni berwarna putih, hitam, hijau tua, dan hitam kecoklatan. Tujuan penelitian ini adalah untuk mengidentifikasi Aspergillus sp pada roti mantao. Metode penelitian ini adalah observasi laboratorik dengan menggunakan media PDA (Potato Dextrose Agar) yang diinkubasi selama 5 hari. Dengan melakukan pengamatan setiap hari pada 10 sampel untuk melihat ada tidaknya pertumbuhan Aspergillus sp pada roti mantao. Hasil pengamatan memperlihatkan adanya pertumbuhan Aspergillus sp pada media PDA (Potato Dextrose Agar) dengan ciri-ciri koloni dengan tekstur seperti kapas (cotton), dengan warna koloni hijau tua. Kesimpulan penelitian ini adalah $10 \%$ roti mantao yang diperjualbelikan di Kota Makassar terkontaminasi Aspergillus sp.
\end{abstract}

Kata kunci : Roti mantao, Aspergillus sp, media PDA (Potato Dextrose Agar).

\section{PENDAHULUAN}

Roti mantao merupakan salah satu pangan semi basah yang biasa di jadikan oleh-oleh khas ataupun di konsumsi sendiri. Makanan ini memiliki rasa lezat dan gurih. Namun ketahanan sebuah roti mantao biasanya tidak lebih dari seminggu atau bahkan hanya beberapa hari setelah kemasan di buka.

Pertumbuhan jamur sering tidak nampak sehingga kadang tidak diperhatikan. Perilaku tersebut seringkali dilakukan oleh masyarakat sehingga bisa mengakibatkan adanya gangguan kesehatan. Pertumbuhan jamur yang sangat cepat pada roti mantao disebabkan oleh bahan dasar dari pembuatan roti tersebut. Salah satunya adalah tepung terigu, yang mana mengandung pati dalam jumlah yang relatif tinggi. Pati ini dapat dihidrolisis menjadi gula sederhana oleh mikroorganisme khususnya Aspergillus sp, karena gula sederhana merupakan sumber nutrisi utama bagi mikoorganisme tersebut (Kusuma, 2008).

Aspergillus $s p$ dapat menghasilkan beberapa mikotoksin. Salah satunya adalah aflatoksin. Aflatoksin merupakan segolongan senyawa yang dikenal mematikan dan karsinogenik bagi manusia dan hewan. Tingginya kandungan aflatoksin pangan akan berbuntut keracunan (Gandahusada, dkk., 2006).

Berdasarkan uraian latar belakang di atas, maka peneliti berkeinginan melakukan penelitian tentang "Identifikasi jamur Aspergillus sp pada roti mantao yang di perjual belikan di Kota Makassar."

\section{METODELOGI PENELITIAN}

\section{Alat dan Bahan}

Alat yang akan digunakan yaitu tabung reaksi, gelas ukur, erlenmeyer, beaker glass, timbangan, batang pengaduk, pipet tetes, cawan petri, autoclave, lampu spiritus, korek api, objek 
glass, deck glass, sendok tanduk, lumpang dan alu, label, pulpen, kaki tiga, kawat kasa, kapas, aluminium foil, inkubator, kawat ose dan mikroskop (sterilkan alat yang akan digunakan terlebih dahulu). Bahan yang digunakan yaitu roti mantao, Media PDA (Potato Dextrose Agar), dan $\mathrm{KOH} 10 \%$.

\section{Prosedur Penelitian \\ Persiapan sampel}

Menyiapkan peralatan yang akan digunakan kemudian mengambil sampel roti mantao yang telah dihaluskan sebanyak 2 gr kemudian dibuat suspensi dengan menambahkan $5 \mathrm{ml}$ aquadest lalu dicentrifuge dengan kecepatan $2000 \mathrm{rpm}$ selama 10 menit. Sampel siap untuk dikultur (Muharram dan Anita 2019).

\section{Pembuatan Media PDA (Potato Dextrose Agar) $200 \mathrm{ml}$ \\ Media PDA (Potato Dextrose Agar)} ditimbang sebanyakk 8,6 gr dimasukkan kedalam erlenmeyer dan ditambahkan aquadest sebanyak $220 \mathrm{ml}$. Selanjutnya untuk mencegah kontaminasi bakteri ditambahkan 1 gram kloramfenikol, kemudian ditutup dengan kapas dan dilarutkan diatas hot plate, kemudian disterilkan dalam autoclave pada suhu $121^{\circ} \mathrm{C}$ selama 15 menit. Setelah proses sterilisasi selesai, media dikeluarkan dari autoclave dihomogenkan. Disiapkan cawa petri diatas meja yang datar, bersih, dan kering, lalu media dalam erlenmeyer tadi dituangkan masing-masing $20 \mathrm{ml}$ kedalam cawan petri (Kidd et al, 2016)

\section{Pembiakan atau kultur}

Sampel yang telah dicentrifuge, supernatannya dipipet sebanyak $1 \mathrm{ml}$ kemudian diisolasi pada Media PDA (Potato Dekstrose Agar) lalu inkubasi pada suhu $30^{\circ} \mathrm{C}$ selama 3 hari. Pengamatan koloni dilakukan setiap hari.

\section{Pemeriksaan mikroskopik}

Koloni yang tumbuh pada Media PDA (Potato Dekstrose Agar) diambil menggunakan Ose atau nal, kemudian diletakkan di atas objek glass lalu ditetesi larutan $\mathrm{KOH} 10 \%$ sebanyak 1 tetes kemudian tutup menggunakan deck glass, lalu amati dibawah mikroskop dengan pembesaran 10x dan 40x.

\section{HASIL PENELITIAN}

Berdasarkan penelitian pada 10 sampel roti mantao yang diperjualbelikan di Kota Makassar dan diteliti di laboratorium mikrobiologi DIII Teknologi Laboratorium Medis Politeknik Kesehatan Muhammadiyah Makassar yang dilaksanakan pada tanggal 8-11 april 2019 diperoleh hasil sebagai berikut:

\section{Tabel 1. Pertumbuhan Jamur Aspergillus sp pada Roti Mantau}

\begin{tabular}{cll}
\hline Kode Sampel & Hasil & \multicolumn{1}{c}{ Keterangan } \\
\hline RM 1 & Negatif (-) & Tidak ditemukan jamur \\
RM 2 & Negatif (-) & Tidak ditemukan jamur \\
RM 3 & Negatif (-) & Tidak ditemukan jamur \\
RM 4 & Negatif (-) & Tidak ditemukan jamur \\
RM 5 & Positif (+) & $\begin{array}{l}\text { Aspergillus fumigatus (Makroskopik; } \\
\text { Koloni seperti kapas dengan warna hijau }\end{array}$ \\
& & tua), (Mikroskopik; Kodia dan vesikel \\
& & bulat, hifa yang tidak bersepta) dan \\
& & $\begin{array}{l}\text { Penicillium sp (Mikroskopik; Membentuk } \\
\text { badan konidium, dan hifa yang bersepta) }\end{array}$ \\
RM 6 & Negatif (-) & Tidak ditemukan jamur \\
RM 7 & Negatif (-) & Tidak ditemukan jamur \\
RM 8 & Negatif (-) & Tidak ditemukan jamur \\
RM 9 & Negatif (-) & Tidak ditemukan jamur \\
RM 10 & Negatif (-) & Tidak ditemukan jamur \\
\hline
\end{tabular}


Penelitian ini bersifat observasi laboratorik yang bertujuan untuk mengidentifikasi Aspergillus sp pada roti mantao. Proses pemeriksaan pada penelitian diawali dengan mengumpulkan 10 sampel roti mantao yang diambil dari tempat yang berbeda. Pengambilan sampel diambil secara accidental sampling yakni mengambil sampel dengan secara kebetulan karena tempat penjualan dari roti mantao tersebut tidak menetap. Pemeriksaan 10 sampel dimulai dengan penanaman pada media PDA (Potato Dextrose Agar), kemudian diinkubasi dengan suhu 300C selama 3 hari. Pengamatan secara makroskopik dilakukan setiap hari. Kemudian pada hari ke 3 dilakukan pemeriksaan kembali secara makroskopik maupun mikroskopik dan ditemukan 1 sampel yang menunjukkan hasil positif terkontaminasi Aspergillus sp.

Pertumbuhan Aspergillus sp pada roti mantao mulai terlihat pada hari ketiga pada sampel RM 5. Pada sampel ditemukan Aspergillus fumigatus dengan ciri-ciri koloni berwarna hijau tua dengan permukaan seperti kapas. Secara morfologi jenis jamur ini memiliki bentuk konidia dan vesikel yang bulat serta memiliki hifa yang tidak bersepta. Pada umumnya pertumbuhan jamur dipengaruhi oleh beberapa faktor seperti faktor subtrat yaitu kandungan yang terdapat pada media biakan, faktor kelembapan yaitu setiap jamur memiliki tingkat kelembapan yang berbeda untuk tumbuh, faktor suhu yaitu secara umum pertumbuhan jamur sekitar 250-300C, dan derajat keasaman substrat $(\mathrm{pH})$ yaitu pada umumnya jamur dapat tumbuh pada kisaran $\mathrm{pH}$ 4-5,5 (Asam/Acid). Juga ditemukan jamur jenis Penicillium sp pada pengamatan mikroskopik dengan ciri-ciri memiliki hifa yang bersepta dan membentuk konidium.

Semakin hari koloni jamur ini semakin membesar karena adanya pertambahan jumlah sel. Hal ini sesuai dengan pernyataan Gandjar, et al (2006) bahwa salah satu parameter pertumbuhan adalah pertambahan volume sel. Pertambahan volume sel tersebut adalah ireversibel, artinya tidak dapat kembali ke volume semula.

Sedangkan untuk sampel RM 1, RM 2, RM 3, RM 4, RM 6, RM 7, RM 8, RM 9, RM 10 tidak ditemukan adanya kontaminasi jamur Aspergillus sp pada sampel. Ini dikarenakan roti mantao tersebut diolah dengan baik, disajikan dengan wadah yang bersih, dan juga disimpan di tempat yang steril. Kemudian sampel RM 5 terkontaminasi Aspergillus sp dikarenakan pada saat pengambilan sampel, roti mantao tersebut memiliki kemasan yang berbeda yaitu tidak memiliki kemasan yang tertutup rapat, berbeda dengan roti mantao yang lainnya yang memiliki kemasan berlapis.

Aspergillus sp dapat tumbuh pada media PDA (Potato Dextrose Agar) karena media tersebut mengandung sumber karbohidrat dalam jumlah yang cukup yang terdiri dari 20\% ekstra kentang dan $2 \%$ glukosa sehingga baik untuk pertumbuhan jamur. Sedangkan roti mantao dapat ditumbuhi jamur karena roti mantao merupakan pangan semi basah dimana jamur mudah tumbuh ditempat yang memiliki kandungan air yang cukup, dan komposisi dari mantao tersebut yang memudahkan jamur untuk tumbuh.

Aspergillus sp merupakan salah satu jamur yang menghasilkan aflatoksin, yaitu toksin yang dapat mematikan manusia karena dapat menyebabkan kanker hati bila sampai masuk kedalam tubuh melalui makanan. Beberapa gejala klinisnya yaitu, muntah, sakit perut, sakit kepala, kejang dan paru-paru membengkak.

Adanya pertumbuhan jamur Aspergillus sp pada media PDA (Potato Dextrose Agar) menandakan bahwa 1dari 10 sampel roti mantao yang diperjualbelikan di Kota Makassar terkontaminasi jamur yang berarti keamanan untuk mengonsumsi pangan harus diperhatikan karena apabila kita 
mengonsumsi makanan yang telah terkontaminasi oleh jamur maka akan menyebabkan berbagai gangguan kesehatan pada manusia.

\section{KESIMPULAN}

Berdasarkan hasil penelitian ini diperoleh kesimpulan bahwa 1 dari 10 sampel roti mantao yang diperjualbelikan di Kota Makassar terkontaminasi Aspergillus fumigatus.

\section{DAFTAR PUSTAKA}

Amalia N. 2012. Identifikasi Jamur Aspergillus flavus Pada Kacang Tanah (Arachis hypogaea L) Yang Dijual Di Pasar Kodim. Jurnal Analis Kesehatan Klinikal Sains, Vol. I, No. 1 Th.2013 : 110.

Carlile, M.J. \& S.C.Watkinson.1994. The Fungi. Academic Press. London.

Denning DW, Riniotis K, Dobrashian R, Sambatakou H. 2003. Kavitas kronis dan fibrosis paru dan pleura aspergillosis: seri kasus, diusulkan perubahan nomenklatur, dan ulasan. Clin Infect Dis. 37 Suppl 3: S265-80.

Edyansyah, E. 2013. Keberadaan Jamur Kontaminan Penyebab Mikotoksikosis Pada Selai Kacang Yang Dijual Di Pasar Tradisional Kota Palembang.
Palembang : Poltekkes Palembang.

Ganjar, Indrawati, Wellyzar Sjamsuridzal dan Ariyanti Oetari, 2006. Mikologi Dasar Terapan. Jakarta : Yayasan Obor Indonesia.

Irianto, K. 2014. Bakteriologi, Mikologi, dan Virologi Medis. Bandung : Alfabet.

Kidd, S., Halliday, C., Alexiau, H., Ellis, D.2016. Descriptions Of Medical. Australia : The national library of Australia.

Kusuma, R 2008. Pengaruh penggunaan cengkeh (Syzgium aromaticum) dan kayu manis (Cinnamomum) sebagai pengawet alami terhadap daya simpan roti manis, skripsi. Bogor : Institut Pertanian Bogor.

Muharram F, Anita. 2019. Penuntun Praktikum Mikologi. Makassar : Akademi Analis Kesehatan Muhammadiyah Makassar.

Pratiwi 2010. Deteksi Ergosterol Sebagai Indikator Kontaminasi Cendawan Pada Tepung Terigu, Vol. XIII, No. 3 Th.2010.

Pratiwi, S. T., 2008. Konsep. Mikrobiologi farmasi. Jakarta : Erlangga.

Siregar, R.S. 2004. Penyakit Jamur Kulit Edisi 2. Jakarta: EGC 